\title{
Ocena jakości wypływki połączeń zgrzewanych doczołowo rur PE typu III wykonywanych bez usuwania warstwy ochronnej
}

\begin{abstract}
W artykule określono kryteria oceny jakości połączenia zgrzewanego doczołowo rur typu III PE/PP zgrzewanych bez usuwania warstwy ochronnej na podstawie wyników geometrii wypływek zgrzewów i przesunięcia ścianek łączonych rur oraz oceny wizualnej.
\end{abstract}

Słowa kluczowe: gazociąg, rury polietylenowe z zewnętrzną warstwą PP, zgrzewanie.

\section{Evaluation of the quality of butt welded joints of PE pipes Type III performed without removing the protective layer}

The article sets out the criteria for the evaluation of the quality of butt fusion joint pipes of the type III PE/PP without removing the protective layer, based on the results of geometry welding burrs and offset walls of the pipes to be connected and visual assessment.

Key words: gas pipeline, polyethylene pipes with an outer layer of PP, welding.

\section{Wprowadzenie}

W Polsce gazociągi są budowane z rur stalowych oraz polietylenowych [10]. Gazociągi polietylenowe, ze względu na właściwości wytrzymałościowe, mogą być wykorzystywane w zakresach ciśnień do 10 bar włącznie [3, 8]. Zastosowanie tego materiału ma już długą historię i sięga lat 70 . ubiegłego wieku. Pierwsze gazociągi budowano z polietylenu pierwszej generacji, tzw. typ 50, o minimalnej wytrzymałości hydrostatycznej na poziomie 6,3 MPa [2]. Na przestrzeni kolejnych lat opracowano nowe surowce, charakteryzujące się zwiększoną wytrzymałością. Minimalna wymagana wytrzymałość (MRS) dla polietylenu PE 100, obecnie powszechnie stosowanego, wynosi $10 \mathrm{MPa}$.

Wraz ze zwiększoną wytrzymałością tego materiału w stosunku do pierwszych surowców polietylenowych uzyskano również większą odporność na powolną propagację pęknięć. Jest to właściwość, która decyduje o odporności rury na wszelkiego rodzaju uszkodzenia jej powierzchni, np. zarysowania. Umożliwiło to wykorzystanie tych rur do renowacji gazociągów stalowych i żeliwnych, polegającej na wprowadzeniu rury PE do starego, nieszczelnego gazociągu.

Jeszcze większy postęp w zakresie technik renowacji gazociągów stalowych czy żeliwnych spowodowało opracowanie materiału polietylenowego o nazwie PE 100-RC, tj. o jeszcze większej odporności na powolną propagację pęknięć i dodatkowo na naciski punktowe. Dzięki tym zaletom rury z polietylenu PE 100-RC wykorzystuje się obecnie w tzw. alternatywnych technikach budowy gazociągów. Różnią się one od techniki tradycyjnej tym, że rura nie musi już być chroniona przed uszkodzeniami przez otaczający ją piasek.

Wśród alternatywnych technik budowy gazociągów można wymienić:

- ułożenie rury PE w gruncie rodzimym (bez podsypki piaskowej),

- metodę płużenia,

- metodę sliplining, 
- metodę przewiertu sterowanego,

- metodę burstlining.

Postępujący rozwój technologii produkcji rur PE umożliwił również wytwarzanie rur warstwowych. Dostępne są obecnie następujące konstrukcje rur [9]:

- rury PE jednowarstwowe - typ I,

- rury PE dwu- lub trójwarstwowe o warstwach połączonych koekstruzyjnie - typ II,

- $\quad$ rury PE z dodatkową zdejmowalną warstwą z polipropylenu (PP) - typ III.

W zależności od wykorzystywanej metody budowy gazociągu należy stosować rury odpowiedniego typu, spełniające określone wymagania. Obecnie brak jest znormalizowanych metod badawczych pozwalających określić odporność rur z polietylenu PE 100-RC na uszkodzenia i oddziaływania, które mogą wystąpić w trakcie układania i eksploatacji gazociągów budowanych technikami alternatywnymi. Jedynym dokumentem określającym metody badań rur PE do stosowania w alternatywnych technikach budowy jest specyfikacja techniczna PAS 1075 [5]. Stanowi ona zbiór wymagań dla surowców polietylenowych oraz dla wykonanych z nich rur. Zgodnie z zapisami PAS 1075 surowce polietylenowe mogą być oznaczane jako RC tylko w przypadku, gdy spełniają wymagania tej specyfikacji. Z punktu widzenia inwestora istotne jest więc, czy rura wyprodukowana $\mathrm{z}$ polietylenu PE 100-RC odpowiada wymaganiom dla wyrobu gotowego zawartym w specyfikacji PAS 1075 (tablica 1).

Tablica 1. Wymagania i badania dla rur PE stosowanych w alternatywnych technikach budowy

\begin{tabular}{|c|l|l|}
\hline Lp. & \multicolumn{1}{|c|}{ Badanie } & \multicolumn{1}{c|}{ Wymaganie } \\
\hline 1. & $\begin{array}{l}\text { Odporność na pęknięcia } \\
\text { naprężeniowe }\end{array}$ & $\begin{array}{l}>3300 \mathrm{~h} \text { przy } 80^{\circ} \mathrm{C} \\
4 \mathrm{~N} / \mathrm{mm}^{2}, 2 \% \text { Arkopal N-100 } \\
\text { (próbki z rury) }\end{array}$ \\
\hline 2. & $\begin{array}{l}\text { Próba obciążenia punk- } \\
\text { towego }\end{array}$ & $\begin{array}{l}8760 \mathrm{~h} \text { przy } 80^{\circ} \mathrm{C} \\
4 \mathrm{~N} / \mathrm{mm}^{2}, 2 \% \text { Arkopal N-100 }\end{array}$ \\
\hline 3. & $\begin{array}{l}\text { Próba penetracji (symu- } \\
\text { lacja odłamka żeliwa } \\
\text { szarego przy wykorzy- } \\
\text { staniu „GG2”) }\end{array}$ & $\begin{array}{l}\text { Pozostała grubość ścianki po } \\
9000 \mathrm{~h}>50 \% \text { początkowej } \\
\text { grubości ścianki }\end{array}$ \\
\hline 4. & $\begin{array}{l}\text { Odporność płaszcza } \\
\text { ochronnego na zaryso- } \\
\text { wania }\end{array}$ & $\begin{array}{l}\text { Głębokość nacięcia może } \\
\text { wynosić po próbie nie więcej } \\
\text { niż 75\% grubości nominalnej } \\
\text { płaszcza ochronnego }\end{array}$ \\
\hline
\end{tabular}

${ }^{3)}$ DVS 2203-4 dodatek 3 [6].

Wymagania przedstawione w tablicy 1, w pozycjach 1-3, odnoszą się do rur typu I, II i rury przewodowej typu III. Odporność płaszcza ochronnego według pozycji 4 dotyczy rur typu III przeznaczonych do szczególnych zastosowań, w których nie jest możliwa kontrola wielkości zarysowania powierzchni rury. Dotyczy to głównie budowy gazociągów z wykorzystaniem przewiertów sterowanych i techniki burstlining.

Przedstawione wymagania według PAS 1075 nie opisują jednak, jakie warunki powinny spełniać miejsca połączeń zgrzewanych metodą doczołową rur typu III.

Zgodnie z wymaganiami normy PN-EN 1555-2:2012 proces zgrzewania doczołowego powinien odbywać się po uprzednim usunięciu płaszcza ochronnego z PP. Po wykonaniu połączenia niezbędne jest więc zabezpieczenie powierzchni rury przewodowej tak, aby nie uległa ona uszkodzeniu zarówno podczas instalacji, jak i użytkowania.

Producenci rur PE typu III proponują różne sposoby zabezpieczenia rur przewodowych w miejscu zgrzewania. Jedną z metod jest usunięcie wypływki zgrzewu z zewnętrznej powierzchni rury, a następnie owinięcie jej powierzchni specjalną taśmą, pod którą wprowadza się masę wypełniającą. Po jej stwardnieniu, jak deklaruje producent, uzyskuje się twardość powierzchni nie mniejszą niż płaszcza ochronnego z PP. Pełną wytrzymałość masa osiąga dopiero po około 15 godzinach.

Innym rozwiązaniem jest zastosowanie muf termokurczliwych. W tym przypadku dochodzi jednak do zwiększenia zewnętrznej średnicy rury w miejscu wykonania zabezpieczenia, a na końcu mufy powstaje krawędź, która przy przeciąganiu rury, np. w technikach przewiertu sterowanego, powoduje dodatkowe opory.

Kolejne rozwiązanie polecane przez producentów rur polega na usunięciu płaszcza ochronnego z rury przewodowej tylko na długości niezbędnej do wykonania zgrzewu. Wówczas powstała wypływka pokrywa miejsce, z którego ściągnięto płaszcz PP. W rozwiązaniu tym jednak po ścięciu wypływki powierzchnia rury przewodowej pozostaje niezabezpieczona.

Z uwagi na powyższe niektórzy producenci zaproponowali wykonywanie zgrzewów doczołowych rur PE typu III bez usuwania warstwy zewnętrznej z PP. Przeprowadzone badania wytrzymałości zgrzewu doczołowego na rozciąganie przygotowanych w ten sposób połączeń zgrzewanych potwierdziły spełnienie wymagań jak dla połączeń zgrzewanych techniką tradycyjną.

Metoda ta pozwala na uzyskanie połączenia zgrzewanego, które nie wymaga dodatkowego zabezpieczania. Po usunięciu wypływki zgrzewu warstwy PP przywierają do siebie powierzchnią czołową i zabezpieczają miejsce zgrzewu (fotografia 1).

Pozostaje jednak kwestia oceny jakości połączenia zgrzewanego metodami nieniszczącymi. W przypadku zgrzewania doczołowego rur PE z usuniętym płaszczem stosuje się kryteria oceny jakości połączenia zgrzewanego na podstawie pomiarów geometrii wypływki. Mierzona jest szerokość wypływki oraz różnice szerokości pomiędzy pojedynczymi wa- 

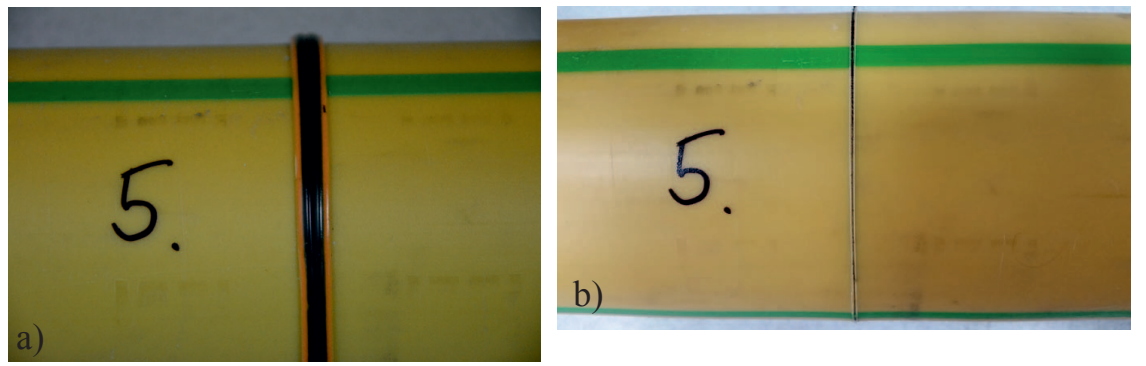

Fot. 1. Zgrzew doczołowy wykonany: a) bez usuwania płaszcza ochronnego z PP przed usunięciem wypływki; b) po usunięciu wypływki łeczkami wypływki. Wyniki pomiarów odnoszone są do ustalonych kryteriów akceptacji. Nie mogą one być jednak wykorzystane do oceny zgrzewów doczołowych wykonywanych bez usuwania warstwy PP. Wynika to głównie z powodu łączenia rur zawierających dwa różne materiały, tj. PE i PP, o różnych wartościach masowego wskaźnika szybkości płynięcia (MFR), który ma duży wpływ na wielkość wypływki zgrzewu.

\section{Kryteria oceny jakości połączeń zgrzewanych rur PE}

Ocenę połączenia zgrzewanego PE bez płaszcza z PP można przeprowadzić poprzez:

- badania nieniszczące,

- badania niszczące [4].

Ze względu na brak efektywnych metod badań nieniszczących kwalifikacja jakości połączeń zgrzewanych odbywa się na podstawie oceny wizualnej i sprawdzenia geometrii [8]. Jest to najszybszy i najtańszy sposób oceny, który praktycznie bezpośrednio po wykonaniu połączenia pozwala stwierdzić, czy zostało ono przygotowane poprawnie. Nie ma jednak możliwości przy ich zastosowaniu sprawdzenia, czy wytrzymałość i żywotność połączenia będzie taka, jak się zakłada. Aby to stwierdzić, należy przeprowadzić badania wytrzymałościowe (niszczące).

W przypadku połączeń zgrzewanych doczołowo podstawowym kryterium oceny jest wypływka zgrzewu [1]. Poprzez pomiar jej geometrii oraz przeprowadzenie oceny wizualnej

Tablica 2. Zestawienie rur wytypowanych do badań - Producent A

\begin{tabular}{|c|c|c|}
\hline Lp. & $\begin{array}{c}\text { Średnica zewnętrzna } \\
d n[\mathrm{~mm}]\end{array}$ & SDR \\
\hline 1. & 110 & 17 \\
\hline 2. & 125 & 11 \\
\hline 3. & 160 & 17 \\
\hline 4. & 180 & 11 \\
\hline 5. & 180 & 17 \\
\hline 6. & 225 & 17 \\
\hline 7. & 250 & 11 \\
\hline
\end{tabular}

Tablica 3. Zestawienie rur wytypowanych do badań - Producent B

\begin{tabular}{|c|c|c|}
\hline Lp. & $\begin{array}{c}\text { Średnica zewnętrzna } \\
d n[\mathrm{~mm}]\end{array}$ & SDR \\
\hline 1. & 110 & 11,0 \\
\hline 2. & 110 & 17,0 \\
\hline 3. & 125 & 17,0 \\
\hline 4. & 160 & 17,0 \\
\hline 5. & 180 & 17,0 \\
\hline 6. & 225 & 17,6 \\
\hline 7. & 250 & 17,0 \\
\hline 8. & 250 & 17,6 \\
\hline
\end{tabular}
można stwierdzić, czy dane po-

W ramach działalności statutowej Instytutu Nafty i Gazu - PIB przeprowadzono badania, których celem było opracowanie kryteriów akceptacji geometrii wypływki zgrzewów doczołowych rur polietylenowych typu III wykonywanych bez usuwania dodatkowego płaszcza ochronnego.

Badania realizowano na próbkach rur polietylenowych wyprodukowanych przez dwóch producentów oznaczanych w dalszej części jako Producent A i Producent B. Próbki rur wytypowanych do badań wyszczególniono w zestawieniu zawartym w tablicach 2 i 3.

łączenie zostało wykonane poprawnie. W warunkach terenowych i laboratoryjnych wszystkie połączenia zgrzewane powinny być kontrolowane i oceniane. Jakość zgrzewu doczołowego rur polietylenowych określamy na następującej podstawie:

- Oględziny zewnętrzne wypływki. Wypływka i jej najbliższe otoczenie nie powinny posiadać żadnych znamion świadczących o wadliwie wykonanym zgrzewie, takich jak: zniekształcenie wypływki, wgłębienia spowodowane zaciskami, widoczne gołym okiem rysy, pęknięcia i pęcherze. Wypływka powinna być gładka i jednolita, wałeczki wypływki powinny być zaokrąglone.

- Ocena zgrzewu przez pomiar geometrii wypływki.

Z przygotowanych próbek rurowych wykonano zgrzewy doczołowe przy założonych parametrach zgrzewania.

Na podstawie przeprowadzonej analizy procesu zgrzewania czołowego, jak również na bazie normy ISO 11414:2009 [7] przyjęto wykonanie połączeń zgrzewanych dla każdej ze średnic w trzech seriach, w następujących warunkach:

- temperatura otoczenia podczas zgrzewania - warunki normalne: $23^{\circ} \mathrm{C}$,

- temperatura otoczenia podczas zgrzewania - warunki minimalne: $0^{\circ} \mathrm{C}$,

- temperatura otoczenia podczas zgrzewania - warunki maksymalne: $30^{\circ} \mathrm{C}$. 
Zgodnie z procedurą zgrzewania w warunkach minimalnych podczas zgrzewania rur czas nagrzewania wstępnego $t_{1}$ wydłużano o 10 sekund, natomiast w warunkach maksymalnych skracano czas $t_{1}$ o 10 sekund w stosunku do czasu ustalonego przez producentów.

Dla osiągnięcia założonego celu pracy na podstawie przeprowadzonej analizy procesu zgrzewania przyjęto, że wyko- nane zgrzewy doczołowe przy założonych parametrach poddane będą kontroli jakości połączeń, obejmującej:

- ocenę wizualną,

- pomiar geometrii wypływki zgrzewów doczołowych.

Do realizacji założonego programu badań wykorzystano zgrzewarki i przyrządy pomiarowe stanowiące wyposażenie Laboratorium Tworzyw Sztucznych Instytutu Nafty i Gazu - PIB.

\section{Analiza wyników}

Podstawowym kryterium akceptacji zgrzewu doczołowego wykonanego ze standardowych rur jest szerokość jego wypływki. Spośród wszystkich wykonanych połączeń zgrzewanych, których ocena wizualna miała wynik pozytywny, wyodrębniono minimalne, średnie i maksymalne wartości szerokości wypływki. Jak wynika z zebranych rezultatów, szerokość wypływki zgrzewów wykonanych bez usuwania warstwy PP nie zmieniała się liniowo w zależności od grubości ścianki rury PE. Podstawowym tego powodem mogła być nieliniowa zmiana grubości warstwy PP w stosunku do grubości ścianki rury PE. Dodatkowo grubość warstwy z PP dla producentów A i B też była zróżnicowana, a ze względu na wyższą temperaturę topnienia fazy krystalicznej polipropylenu warstwa z PP ma szczególny wpływ na uzyskiwane wartości szerokości wypływki.

Z uwagi na powyższe nie było możliwe ustalenie kryterium oceny szerokości wypływki zgrzewu doczołowego rur typu III bez usuwania warstwy.

Szerokość wypływki zgrzewu to jednak nie jedyne kryterium oceny połączenia zgrzewanego. Istotny jest np. kształt wypływki, na który ma wpływ wiele czynników. Aby uniknąć uzyskania zgrzewów niewłaściwej jakości przy zgrzewaniu rur PE typu III, należy przestrzegać następujących zaleceń:

1. Zgrzewać doczołowo bez usuwania warstwy PP można rury typu III, dla których producenci deklarują tę możliwość i podają parametry zgrzewania uwzględniające większą powierzchnię czołową rur (siła docisku, czas zgrzewania).

2. Należy stosować zgrzewarki zautomatyzowane z możliwością automatycznego usunięcia płyty grzewczej (skrócenie do minimum oraz uzyskanie powtarzalnego czasu usuwania płyty grzewczej i połączenia ze sobą uplastycznionych powierzchni rur).

3. Zgrzewarka powinna mieć możliwość wprowadzenia wymaganych parametrów zgrzewania niezbędnych do ustalenia ciśnienia zgrzewania, czasu usunięcia płyty grzewczej (np. nacisk jednostkowy, całkowita grubość ścianki rury PE plus grubość warstwy PP, czas zgrzewania). Prawidłowość ustalenia parametrów zgrzewania powinna zostać potwierdzona przez producenta zgrzewarki lub jego przedstawiciela.

4. Zgrzewarka powinna mieć możliwość rejestracji wszystkich parametrów procesu zgrzewania oraz wydruku protokołu zgrzewania. W przypadku niedotrzymania któregoś z parametrów na drukowanym protokole powinien być wskazany identyfikowalny błąd procesu zgrzewania.

5. Zgrzewarka powinna być wyposażona w odpowiednie wkłady redukcyjne do mocowania rur w układzie mocująco-scalającym zgrzewarki, dopasowane do zewnętrznej średnicy rury (większa średnica zewnętrzna rury ze względu na dodatkową warstwę PP). Ze względu na różne grubości tej warstwy u różnych producentów wkłady powinny być dobrane indywidualnie.

6. Rury w uchwytach zgrzewarki powinny być zamocowane współosiowo, a ich dopuszczalne przesunięcie względem siebie nie powinno być większe niż 10\% sumy nominalnej grubości ścianki rury PE i warstwy z PP.

7. Kontrola jakości frezowania powinna polegać na ocenie maksymalnej wielkości szczeliny pomiędzy dociśniętymi powierzchniami rur. Szczelina powinna spełniać wymagania jak dla standardowej procedury zgrzewania rur PE.

8. Procedurę zgrzewania należy realizować zgodnie z instrukcją obsługi zgrzewarki.

\section{Kryteria akceptacji geometrii wypływki połączeń zgrzewanych doczołowo rur PE typu III wykonywanych bez usuwania warstwy ochronnej}

Na podstawie przeprowadzonej oceny jakości połączenia zgrzewanego doczołowo (wyniki geometrii wypływek zgrzewów, przesunięcia ścianek łączonych rur, ocena wizualna) opracowano kryteria akceptacji geometrii wypływki. W tablicy 4 zamieszczono katalog defektów mogących powstać podczas zgrzewania czołowego rur PE typu III wykonywanego bez usuwania warstwy ochronnej. Przedstawiono schematycznie wypływki zgrzewów, zamieszczono również fotografie obra- 
zujące odniesienie teoretycznych wad do rzeczywistych błędów w połączeniach i przedstawiono Kryteria oceny jakości połączenia zgrzewanego doczołowo rur PE typu III wykonywanego bez usuwania warstwy ochronnej.

Tablica 4. Kryteria akceptacji geometrii wypływki połączeń zgrzewanych doczołowo rur PE typu III wykonywanych bez usuwania warstwy ochronnej

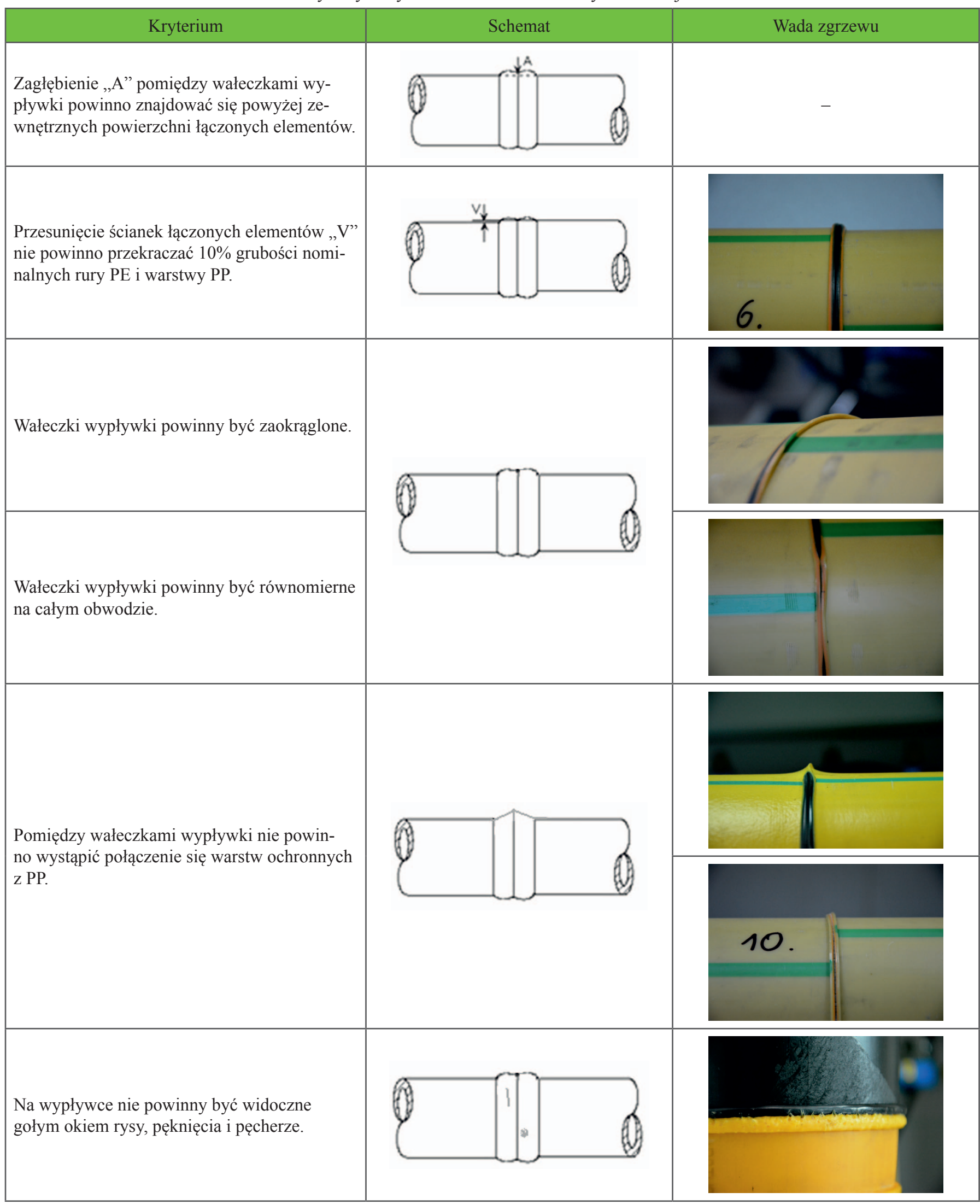




\section{Stwierdzenia i wnioski}

1. Zgrzewanie rur PE typu III bez usuwania warstwy PP należy prowadzić według parametrów zgrzewania określonych przez producentów rur ze zwróceniem szczególnej uwagi na ustalenie ciśnienia w układzie hydraulicznym zgrzewarki uwzględniającego zwiększoną powierzchnię przekroju rury - o powierzchnię wynikającą z nieusuniętej warstwy PP.

2. Z uwagi na wyższą temperaturę topnienia fazy krystalicznej PP w stosunku do PE powinno się dążyć do jak najszybszego wyjęcia płyty grzewczej i połączenia ze sobą uplastycznionych powierzchni rur. Czas trwania tej operacji ma duży wpływ na końcowy kształt wypływki zgrzewu - zbyt długi może powodować, że będzie ona zbyt wąska lub nie uformuje się w postaci owalnych wałeczków.

3. Zapewnienie minimalnego i powtarzalnego czasu wyjęcia płyty grzewczej i połączenia rur ze sobą można uzy- skać przez stosowanie zgrzewarek zautomatyzowanych $\mathrm{z}$ automatycznym systemem usuwania płyty grzewczej.

4. Jakość połączenia zgrzewanego doczołowo rur PE typu III wykonanego bez usuwania warstwy ochronnej z PP powinna być sprawdzana na podstawie:

- oceny karty technologicznej zgrzewania pod kątem zgodności ustalonej procedury zgrzewania z zaleceniami producenta rury,

- oceny zgodności rzeczywistej procedury zgrzewania opartej na protokole zgrzewania (wydruk z rejestratora parametrów zgrzewania),

- sprawdzenia warunków środowiskowych oraz jakości przygotowania elementów do zgrzewania na zgodność Z wymaganiami jak dla standardowych rur PE,

- oceny wizualnej wypływki na zgodność z opracowanymi kryteriami.

Prosimy cytować jako: Nafta-Gaz 2016, nr 12, s. 1113-1118, DOI: 10.18668/NG.2016.12.15

Artykuł nadesłano do Redakcji 8.11.2016 r. Zatwierdzono do druku 28.11.2016 r.

Artykuł powstał na podstawie pracy statutowej pt. Kryteria akceptacji geometrii wyplywki połaczeń zgrzewanych doczołowo rur PE typu III wykonywanych bez usuwania warstwy ochronnej - praca INiG - PIB na zlecenie MNiSW, nr zlecenia: 0048/GP/15, nr archiwalny DK-4100-0048/15.

\section{Literatura}

[1] Barczyński A., Roszkowski A.: Kontrola jakości połączeń doczołowych rur PE za pomoca pomiarów geometrycznych wyptywki. Gaz, Woda i Technika Sanitarna 2010, nr 12, s. 2-6.

[2] Szewczyk P.: Badania odporności na oddziaływania punktowe rur polietylenowych warstwowych uktadanych w gruncie rodzimym, przeznaczonych do przesyłania gazu. Nafta-Gaz 2012, nr 9, s. 611-616.

[3] Szewczyk P.: Stabilizacja ciśnienia i temperatury czynnika próby przed rozpoczęciem badania szczelności gazociagów polietylenowych. Nafta-Gaz 2014, nr 5, s. 307-312.

[4] Zasady projektowania i budowy sieci gazowych. Wytyczne kontroli połaczeń doczołowych i elektrooporowych na gazociagach polietylenowych. PSG Sp. z o.o., Oddział w Poznaniu, wydanie 2 z 17.07.2014.

\section{Akty prawne i normatywne}

[5] DIN PAS 1075:2009 Rohre aus Polyethylen für alternative Verlegetechniken - Abmessungen, technische Anforderungen und Prüfung. Rury wykonane z polietylenu do zastosowania $w$ alternatywnych technikach ukladania - Wymiary, wymagania techniczne i badanie. Publikacja PAS1075 (PAS = publicly available specification).

[6] DVS 2203-4 dodatek 3 Testing of welded joints between panels and pipes made of thermoplastics - Tensile creep-rupture test - Checking of the demanded tensile creep-rupture welding factor and of the minimum service life of welded joints between polyethylenes (PE 80 and PE 100).
[7] ISO 11414:2009 Plastics pipes and fittings. Preparation of polyethylene (PE) pipe/pipe or pipe/fitting test piece assemblies by butt fusion.

[8] PN-EN 12007-2:2013-02 Infrastruktura gazowa. Rurociagi o maksymalnym ciśnieniu roboczym do 16 bar włacznie. Część 2: Szczegółowe wymagania funkcjonalne dotyczace polietylenu (MOP do 10 bar włącznie).

[9] PN-EN 1555-2:2012 Systemy przewodów rurowych z tworzyw sztucznych do przesytania paliw gazowych. Polietylen (PE). Część 2: Rury.

[10] Rozporządzenie Ministra Gospodarki z dnia 26 kwietnia 2013 r. w sprawie warunków technicznych, jakim powinny odpowiadać sieci gazowe i ich usytuowanie (Dz. U. z 2013 r., poz. 640).

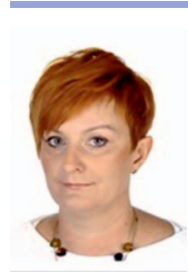

Mgr inż. Anna WRÓBLEWSKA

Starszy specjalista badawczo-techniczny w Zakładzie Przesyłania i Dystrybucji Gazu - Laboratorium Tworzyw Sztucznych. Instytut Nafty i Gazu - Państwowy Instytut Badawczy ul. Lubicz 25 A, 31-503 Kraków

E-mail: anna.wroblewska@inig.pl 